\title{
Elastofibroma dorsi - differential diagnosis in chest wall tumours
} Adrien Daigeler*1, Peter Maria Vogt ${ }^{2}$, Kay Busch², Werner Pennekamp ${ }^{3}$, Dirk Weyhe ${ }^{4}$, Marcus Lehnhardt ${ }^{1}$, Lars Steinstraesser ${ }^{1}$, Hans-Ulrich Steinau ${ }^{1}$ and Cornelius Kuhnen ${ }^{5}$

\begin{abstract}
Address: ${ }^{1}$ Department of Plastic Surgery, Burn Center, Hand Center, Sarcoma Reference Center, BG-Hospital "Bergmannsheil", Ruhr-University Bochum, Bürkle-de-la-Camp-Platz 1, 44789 Bochum, Germany, 2Department of Plastic, Hand, and Reconstructive Surgery, Burn Center, Hannover Medical School, Podbielskistr. 380, 30659 Hannover, Germany, ${ }^{3}$ Institute of Diagnostic Radiology, Interventional Radiology and Nuclear Medicine, BG-Hospital "Bergmannsheil", Ruhr-University Bochum, Bürkle-de-la-Camp-Platz 1, 44789 Bochum, Germany, ${ }^{4}$ Department of Surgery, St. Josef Hospital - University Medical Center, Ruhr University of Bochum, Gudrunstr. 56, 44791Bochum, Germany and 5Pathology, BG-Hospital "Bergmannsheil", Ruhr-University Bochum, Bürkle-de-la-Camp-Platz 1, 44789 Bochum, Carl-Neuberg-Str. 1, 39625 Hannover, Germany
\end{abstract}

Email: Adrien Daigeler* - adrien.daigeler@rub.de; Peter Maria Vogt - vogt.peter@mh-hannover.de; Kay Busch - kay.busch@cityweb.de; Werner Pennekamp - werner.pennekamp@rub.de; Dirk Weyhe - d.weyhe@elis-stiftung.de; Marcus Lehnhardt - marcus.lehnhardt@rub.de; Lars Steinstraesser - lars.steinstraesser@rub.de; Hans-Ulrich Steinau - hans-ulrich.steinau@bergmannsheil.de; Cornelius Kuhnen - cornelius.kuhnen@rub.de

* Corresponding author

Published: 5 February 2007

World Journal of Surgical Oncology 2007, 5:15 doi:10.1186/1477-7819-5-15
Received: 5 December 2006

Accepted: 5 February 2007

This article is available from: http://www.wjso.com/content/5/I//5

(c) 2007 Daigeler et al; licensee BioMed Central Ltd.

This is an Open Access article distributed under the terms of the Creative Commons Attribution License (http://creativecommons.org/licenses/by/2.0), which permits unrestricted use, distribution, and reproduction in any medium, provided the original work is properly cited.

\begin{abstract}
Background: Elastofibromas are benign soft tissue tumours mostly of the infrascapular region between the thoracic wall, the serratus anterior and the latissimus dorsi muscle with a prevalence of up to $24 \%$ in the elderly. The pathogenesis of the lesion is still unclear, but repetitive microtrauma by friction between the scapula and the thoracic wall may cause the reactive hyperproliferation of fibroelastic tissue.

Methods: We present a series of seven cases with elastofibroma dorsi with reference to clinical findings, further clinical course and functional results after resection, as well as recurrence. Data were obtained retrospectively by clinical examination, phone calls to the patients' general practitioners and charts review. Follow-up time ranged from four months to nine years and averaged 53 months.

Results: The patients presented with swelling of the infrascapular region or snapping scapula. In three cases, the lesion was painful. The ratio men/women was $2 / 5$ with a mean age of 64 years. The tumor sizes ranged from 3 to $13 \mathrm{~cm}$. The typical macroscopic aspect was characterized as poorly defined fibroelastic soft tissue lesion with a white and yellow cut surface caused by intermingled remnants of fatty tissue. Microscopically, the lesions consisted of broad collagenous strands and densely packed enlarged and fragmented elastic fibres with mostly round shapes. In all patients but one, postoperative seroma (which had to be punctuated) occurred after resection; however, at follow-up time, no patient reported any decrease of function or sensation at the shoulder or the arm of the operated side. None of the patients experienced a relapse.
\end{abstract}

Conclusion: In differential diagnosis of soft tissue tumors located at this specific site, elastofibroma should be considered as likely diagnosis. Due to its benign behaviour, the tumor should be resected only in symptomatic patients. 


\section{Background}

Elastofibromas are slowly growing benign tumors of soft tissue origin. In $99 \%$ of the cases, they are located in the inferior subscapular region between the scapula and the thoracic wall; they consist of fragmented and enlarged elastic fibres embedded in collagenous matrix that often occur bilaterally [1-4]. They are commonly found in active subjects beyond their $50^{\text {th }}$ year [1-4], but may also affect children [5]. In elderly patients, this tumor was incidentally found in up to $2 \%$ by CT imaging [6]. Autopsy studies reported an even higher incidence of $13 \%$ to $17 \%$, revealing pre-elastofibroma-like morphologic changes even in $81 \%$ of the autopsies $[7,8]$. In subjects over 55 years of age, prevalence is given with up to $24 \%$ [8]. In the differential diagnosis of soft tissue tumors located at the thoracic wall, one should be aware of this surprisingly common lesion. We followed up a series of seven cases with reference to clinical findings, further clinical course and functional result after resection, as well as recurrence.

\section{Patients and methods}

Data for this case series were acquired retrospectively from the patients' charts, physical examination and phone calls to their general practicioners. From 1996 to 2005, seven patients with diagnosis elastofibroma dorsi were treated at our institutions (two center study).

All patients underwent MRI imaging preoperatively. Three patients were core biopsied in advance; for two patients, the diagnosis was made by instantaneous section. Two patients were primarily resected completely without preor intraoperative histopathologic verification of the diagnosis. In all patients, marginal complete resection was performed and tissue specimens were sent in for patho- logical evaluation to an experienced soft tissue pathologist. Defects were closed primarily.

\section{Results}

Five patients were female; two were male. The average age at the time of the treatment was 63.7 years and ranged from 46 to 79 years. Follow-up data was available for all patients. Follow-up time ranged from four months to nine years and averaged 53 months.

The tumors were attached to the thoracic wall, located between the serratus anterior muscle and the chest wall in their anterior and between serratus and latissimus dorsi muscle in their posterior extension (figure 1). In four cases, the tumor was located at the right side; in two cases, at the left side; and, in one patient, it was growing bilaterally. In only three cases, the lesion was located at the side of the dominant hand. None of the patients was extensively active during their lifetime. In most of the patients, the predominant symptoms were swelling and snapping of the scapula. The tumor sizes ranged from 3 to $13 \mathrm{~cm}$. On MRI in all patients the margins of the elastofibromas were well defined. The tumors were located inferior to the margo inferior of the scapula, adjacent to the thorcic wall. The central parts contained fibrous masses with low signal intensity on T1- and T2-weighted images. Hyperintens signals in T1- and T2- weighted images represented intermingled fatty tissue. On STIR-sequences the fatty tissue also showed low signal intensity, with a slightly higher intensity of the the fibrous tissue. Focal aereas of high signal intensity STIR-sequences may also be interpreted as edema within the lesion. In figure 2 the typical aspect of a bilateral elastofibroma on MRI is shown (figure 2).

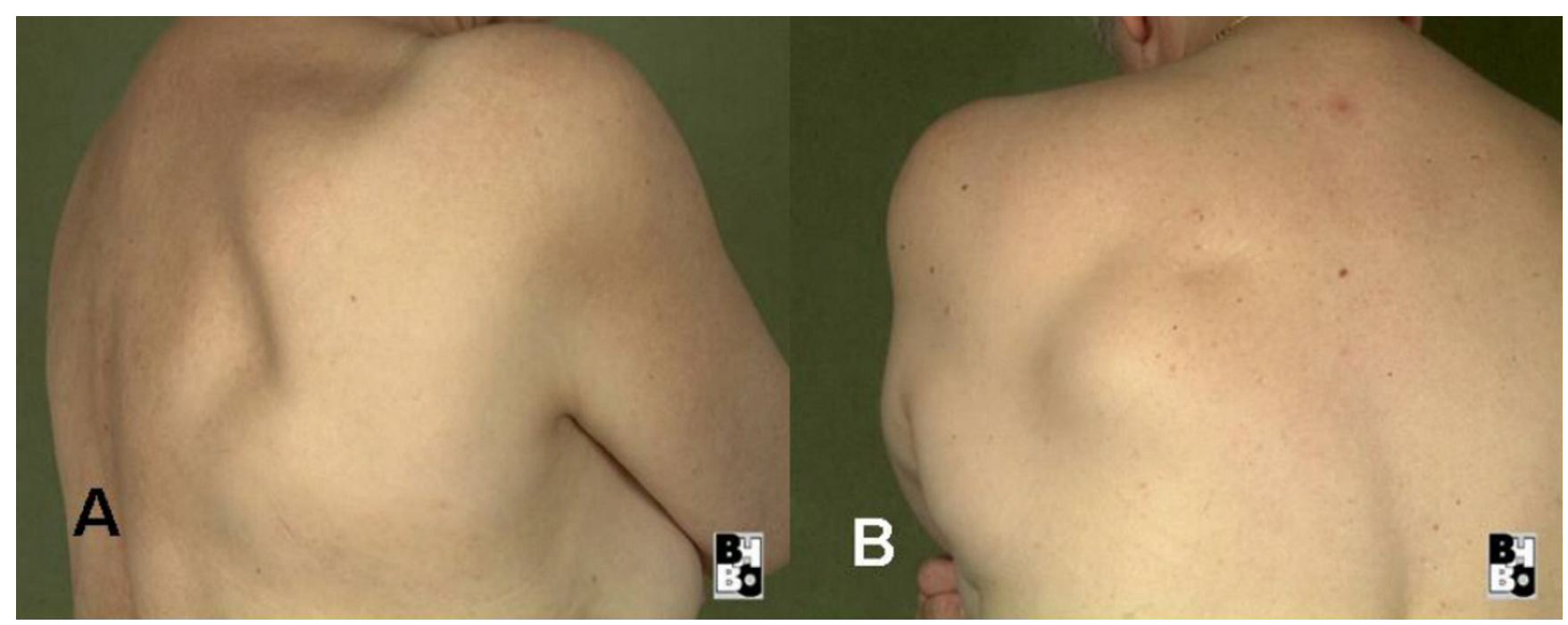

Figure I

Photographs of the tumour aspect of patients I (a) and I (b). 


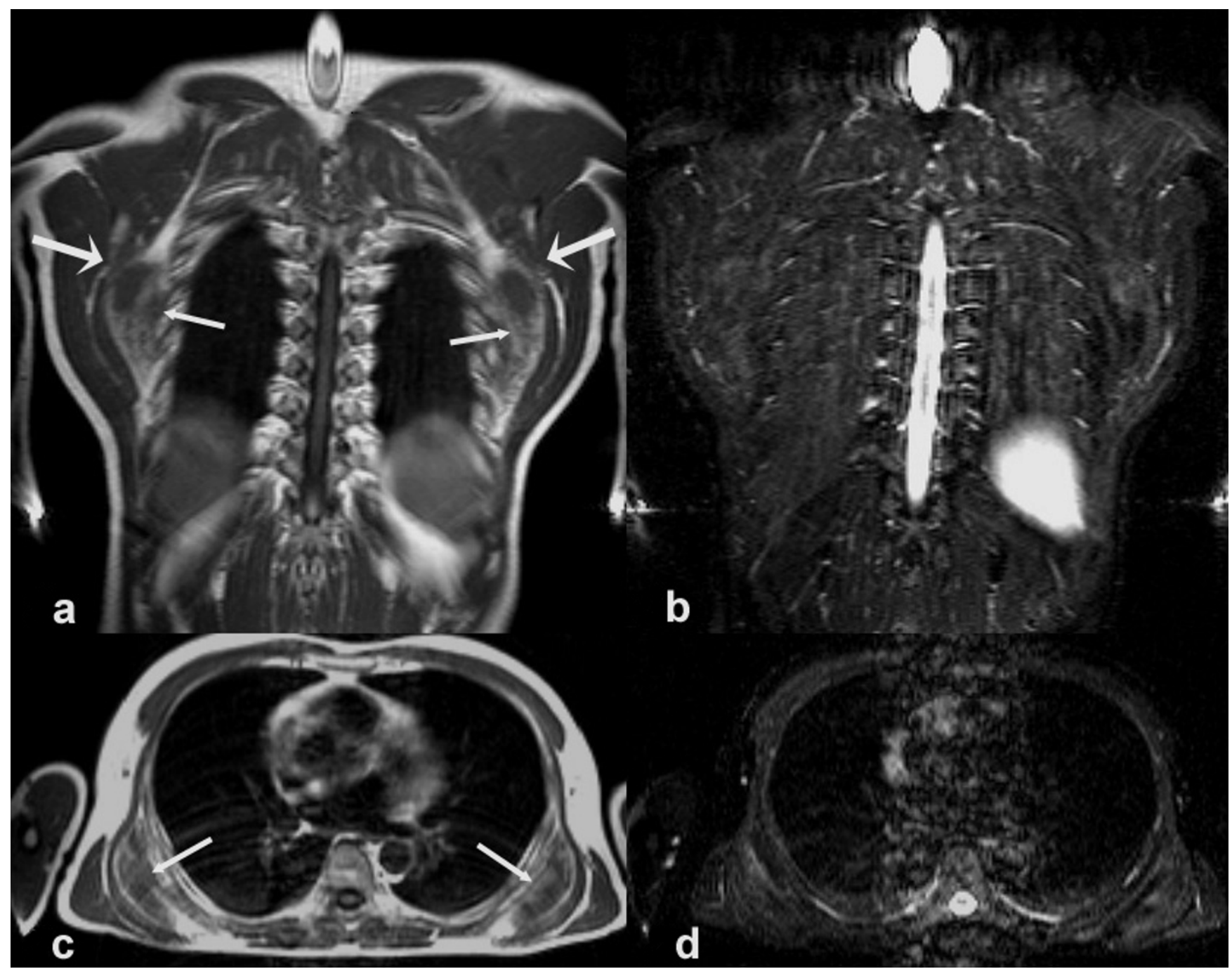

Figure 2

MRI of bilateral elastofibroma with the tumour being located between the thoracic wall, the anterior serratus, and the latissimus dorsi muscle (coronal (2a) and axial (2c) TI-weighted images): The small arrows indicate the medial margins of the lesions containing fatty (bright) and fibrous (dark) tissue. The tumours are located between the thoracic wall, the anterior serratus, and the latissimus dorsi muscle. The large arrows points to the margo inferior of the scapula. Figures [2b] and [2d] show the corresponding STIR -sequences with a slightly inhomogenous signal intensity within the elastofibromas.

In one patient, dyspnea and hypertension occurred coincidentally with the elastofibroma and disappeared with tumor resection. Due to the mild disturbances caused by the lesions, the patients sought medical advice only late after the onset of the symptoms ( 4 months to 4 years). In all patients but one, postoperative seroma (which had to be punctuated) occurred; however, at follow-up time, no patient reported any decrease of function or sensation at the shoulder or the arm of the operated side. No relapse of the tumor occurred. One patient could not be followed up personally as the patient died of cerebral apoplexy 13 months after treatment. At that time, however, the patient had neither recurrence of the elastofibroma nor any dis- turbances caused by the tumor resection. A detailed summary of the patients' data is given in table 1 .

\section{Pathology}

Macroscopic findings: The soft tissue lesions were typically characterized by an irregular, poorly defined fibroelastotic mass with a slightly rubbery, elastic consistence. The cut surface showed strands of white and yellow tissue caused by the entrapment of fatty remnants, similar to a "checkerboard" pattern (figure 3). The tumours were not encapsulated. Microscopic findings: Histologically, all tumors were composed of fibrous, collagenous strands and plump, sometimes elongated mostly round-shaped 


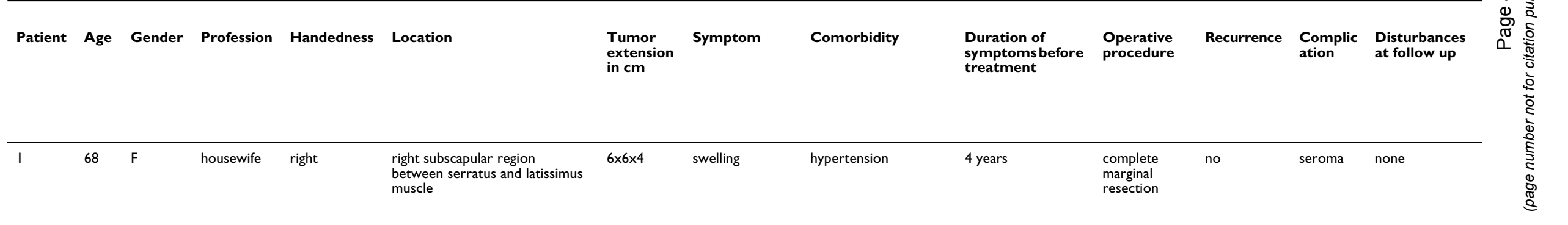
76 F housewife right

$\begin{array}{lll}\text { right subscapular region } & 12 \times 7 \times 5\end{array}$ muscle

$$
\frac{2}{3}
$$
left subscapular region between

$5.5 \times 5 \times 2 \quad$ swelling hypertension,
hyperthyreosis

4 months

complete marginal
resection

no

coronary artery

9 months mellitus Ilb

swelling

Leiomyosarcoma both 2 years lower leg,s
gonarthrosis

between serratus and latissimus

marginal resection

complete marginal

seroma

none, died of apoplexy months afte treatment

\begin{tabular}{|c|c|c|c|c|c|c|c|c|c|c|c|c|c|}
\hline 5 & 47 & M & engineer & right & $\begin{array}{l}\text { left subscapular region betweeen } \\
\text { latissismus and serratus muscle }\end{array}$ & $5 \times 4 \times 2$ & pain & hypertension & 4 years & $\begin{array}{l}\text { complete } \\
\text { marginal } \\
\text { resection }\end{array}$ & no & $\begin{array}{l}\text { hematom } \\
\text { a }\end{array}$ & none \\
\hline & & & & & $\begin{array}{l}\text { right subscapular region } \\
\text { between latissimus, serratus, and } \\
\text { rhomboideus maj. muscle }\end{array}$ & $13 \times 1 \mid \times 3$ & pain & & 4 years & $\begin{array}{l}\text { complete } \\
\text { marginal } \\
\text { resection }\end{array}$ & no & seroma & none \\
\hline 6 & 59 & M & engineer & right & $\begin{array}{l}\text { right subscapular region, } \\
\text { between latissismus and serratus } \\
\text { muscle }\end{array}$ & $9 \times 7 \times 2.5$ & pain & none & 1.5 years & $\begin{array}{l}\text { complete } \\
\text { marginal } \\
\text { resection }\end{array}$ & no & $\begin{array}{l}\text { hematom } \\
\text { a, seroma }\end{array}$ & none \\
\hline 7 & 79 & $\mathrm{~F}$ & housewife & right & $\begin{array}{l}\text { left subscapular region, between } \\
\text { latissismus and serratus muscle }\end{array}$ & $6.5 \times 2.5 \times 5$ & $\begin{array}{l}\text { swelling dyspnea } \\
\text { hypertension }\end{array}$ & arteriosclerosis & I year & $\begin{array}{l}\text { complete } \\
\text { marginal } \\
\text { resection }\end{array}$ & no & seroma & $\begin{array}{l}\text { none, complete } \\
\text { remission of } \\
\text { dyspnea and } \\
\text { hypertension }\end{array}$ \\
\hline
\end{tabular}


elastic fibres which were densely packed. The elastic structures typically formed discs or globules and sometimes appeared in an "asbestos-body-like" fashion. These fibres were difficult to detect using hematoxylin-eosine-staining, especially during the frozen section procedure. They were best highlighted using elastic stain (Elastica-van-Gieson) which stained the fibres dark brown to black. The lesions were predominantly hypocellular with fibrocytic and fibroblastic cells without atypia and mitotic activity (figure $4 \mathrm{a}-\mathrm{c})$.

\section{Discussion}

The pathogenesis of elastofibroma dorsi is still unclear, but repetitive microtrauma caused by friction between the scapula and the thoracic wall may cause reactive hyperproliferation of fibroelastic tissue [9-13]. A systematic review of the literature gave no further hints to the role of microtraumatization because most authors did not provide any information about their patients' activity. There is a striking predominance of the female gender from 5:4 to $13: 1$, depending on the study, suggesting that microtrauma alone cannot be the major factor in genesis of this lesion [1-4]. Previous publications referred to other sites of friction exposure as the tricuspid valve, axilla, foot, and ischial tuberosity; however, other reports of less common sites of manifestation with lower mechanical stress like the mediastinum, the stomach, the greater omentum, the inguinal region, the orbita, and the intraspinal space support this theory $[3,11,14-18]$. With the tumors occurring at the dominant and nondominant hand site in our patients, there seemed to be no association to mechanic stress assuming the dominant side was exposed to a higher level of repetitive microtrauma during lifetime. Additionally, only one of our patients had a history of extensive physical activity in his life (canoeist). Several authors proposed vascular insufficiency as a possible reason for the degenerative changes $[8,12]$. A familial predisposition with an underlying enzymatic defect may exist in $30 \%$, but this has never been finally proved $[2,19,20]$. Large case series from Japan strongly suggest that hereditary factors may be a predisposition for this lesion $[2,21]$. The nature of the altered elastic fibres is disputed and controversial. They may be caused by abnormal elastogenesis or by degenerating as a secondary process, or even by a combination of both processes $[8,13,20,22,23]$.

The symptoms of elastofibroma dorsi depend on the site and size of the lesion and may present as shoulder pain or

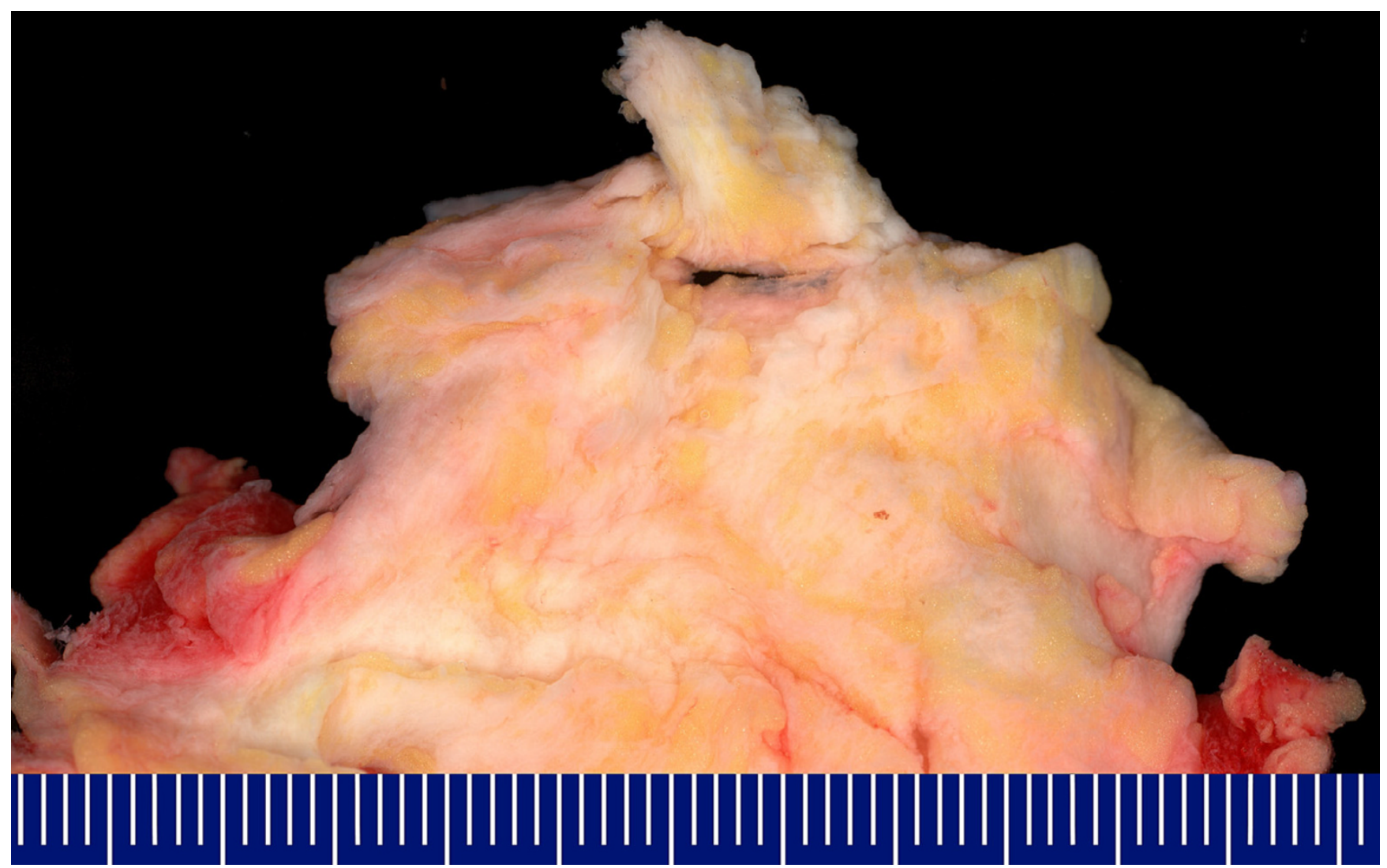

Figure 3

Macroscopic aspect of elastofibroma dorsi: Poorly defined fibroelastotic tumor with entrapment of fatty remnants. 


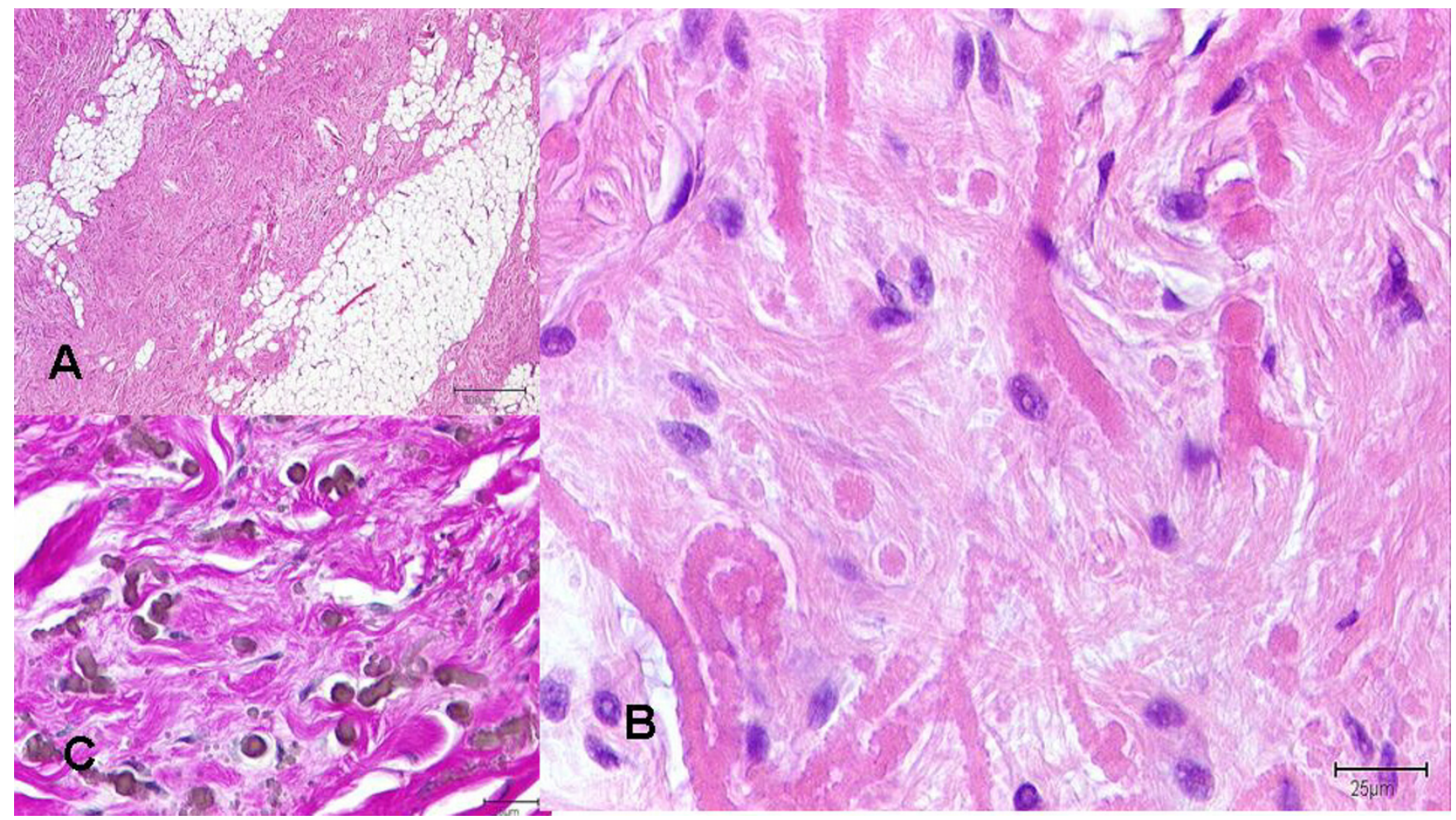

\section{Figure 4}

Microscopic findings in elastofibroma dorsi: 4a): Fibrous, collagenous strands intermingled with fat cells (hematoxylin-eosinestaining). 4b): Collagenous material and roundly shaped elastic fibres, mesenchymal cells with bland nuclei (hematoxylin-eosinestaining). 4c): Elastic fibres and structures forming discs and globules stained dark brown to black using an elastic stain (Elasticavan-Gieson).

snapping scapula as in our patients. In $50 \%$ of the cases, the tumor remains asymptomatic or causes mild discomfort only, explaining the long periods of up to 67 years between the onset of the symptoms and treatment [1$4,24,25]$. Large lesions may simulate scapula alata, by elevating the scapula. If palpable, the tumor may mimic semimobility due to its elastic fibres, but intraoperatively it normally shows adherent to the surrounding tissue. It occurs predominantly at the right side but, in up to $50 \%$ of the cases, it is found bilaterally [8]. In our collective, this proportion was $14 \%$. The coincidence of hypertension and dyspnea with elastofibroma has not yet been described and may be unrelated, whereas a large tumor may disturb thoracic elasticity and movements and therefore could cause dyspnea by interfering with the breathing motor function.

Aside from a possible soft tissue signal intensity or elevated scapula, plain radiographs do not show specific changes. On MRI, probably the most reliable non-invasive technique in diagnosis, the lesions mostly show a signal intensity, comparable to that of muscle, margins are well defined and signal intensity is mostly low. Interspersed adipose strands cause a heterogeneous structure with longitudinal areas of higher signal intensity $[4,11,26-$ 29]. In all of our patients the findings on MRI were consistent with the criteria mentioned above. After application of contrast agent, normally faint but also marked enhancement mimicking malignancy may be observed [30-32]. CT shows the same changes but is less sensitive for visualizing the strands of fatty tissue [29]. On PET-CT radiotracer accumulation of the hypermetabolic tumor has been described [33]. Differential diagnosis includes sarcomas, aggressive fibromatosis, lipoma, and fibroma. Ultrasound patterns of the tumor are characteristic including fasciculated structures with hypo- and hyperechogeneous striae of different thickness similar to that of muscle tissue but less organized. Colour Doppler shows vascularization patterns similar to the surrounding muscle. In the hands of an experienced examiner, ultrasound may represent a quick and cheap diagnostic tool [34-36]. Due to its muscle like appearance in all of the imaging procedures mentioned, the lesion may go undiagnosed or, in case of abnormal features, misdiagnosed. The advanced age of the patients, the typical localization, female gender or bilateral manifestation support the presumptive diagnosis of elastofibroma. In these cases and with clear imaging findings, one may refrain from biopsy. In all other cases, 
in contrast to other authors [26,28,37-40], we strongly recommend that tumor material be obtained to confirm the presumptive or to establish another diagnosis, because MRI, CT or ultrasound and clinical findings cannot give final safety $[1,2,32,41-45]$. Fine needle aspiration [46] is not recommended because of the inherent hypocellularity of the tumor. An open biopsy or at least a core needle biopsy should be performed to get a representative tissue specimen. Histomorphologically, the diagnosis is based on the presence of the altered elastic fibres embedded in a collagenous matrix, riddled with various amounts of fat cells. These elastic fibres are often fragmented into discs or globules and larger than regular ones $[13,20,47]$. Ultrastructurally, the elastinophilic material frequently contains a central core of mature elastic tissue and appears to be secreted by active fibroblasts; this further substantiates the thesis that the elastic material in elastofibroma is derived from excessive production by fibroblasts rather than from elastotic degeneration of collagen. Dense granular bodies within the fibroblast cytoplasm are described, which are thought to represent elastin or elastin precursors [48].

In incidental diagnosis of asymptomatic lesions there is no need for excision as malignant transformation has never been described. Only in cases of discomfort, snapping or blocking scapula and pain, marginal resection is widely recommended according to the psychological and physical strain of the patient $[1,2,49]$, but anecdotal reports mentioned good results with radiotherapy as well $[16,17]$. This may be an option especially for manifestations in unresectable locations. The high incidence of seromas in our patients, whereas there is no report about seromas in the literature, may be a result of insufficient immobilisation. Taking into account the usually advanced age of the patients, immobilisation bears the risk of remaining stiffness in the shoulder girdle, whereas punctuation of a seroma may only prolong reconvalescence and cause mild discomfort. Our patients retrospectively did not experience postoperative seroma as relevant discomfort. All patients were free of the disease at followup time, concurring with the literature reporting only a few cases of recurrence $[2,32,50]$.

\section{Conclusion}

In differential diagnosis of soft tissue tumors located at the infrascapular region, elastofibroma should be considered as likely diagnosis by the surgeon and the surgical pathologist. We prefer MRI to localize and identify the lesion. In elderly patients or patients with bilateral manifestation and definite findings in imaging, it may be justified to refrain from biopsy. Otherwise, open biopsy should be performed to exclude malignancy and to reassure the asymptomatic patient that no surgical treatment is necessary. Unnecessary wide and radical resections in the symptomatic patient can be avoided because marginal resection has proven to be sufficient. We recommend postoperative wound drainage and compression garment, as well as shoulder immobilization for one week to reduce postoperative seroma.

\section{Competing interests}

The author(s) declare that they have no competing interests.

\section{Authors' contributions}

$\mathrm{AD}$ conceptualised the study, gathered the data and wrote the manuscript.

PV analysed and interpreted the data.

KB acquired and weighed the data.

WP evaluated the MRI findings and edited the radiology section.

DW was involved in drafting the manuscript and critically revising it.

ML interpreted the data and revised the manuscript.

LS reviewed the literature and analysed the data.

HS initiated the study and supervised the process. He gave final approval for publication.

CK performed the histopathological evaluation and interpretation of the data.

\section{Acknowledgements}

We thank Amanda Daigeler for her formal English revision of the manuscript

\section{References}

I. Briccoli A, Casadei R, Di Renzo M, Favale L, Bacchini P, Bertoni F: Elastofibroma dorsi. Surg Today 2000, 30(2): I47-I52.

2. Nagamine N, Nohara $Y$, Ito E: Elastofibroma in Okinawa. A clinicopathologic study of I 70 cases. Cancer I 982, 50(9): | 794- I 805.

3. Naylor MF, Nascimento AG, Sherrick AD, McLeod RA: Elastofibroma dorsi: radiologic findings in 12 patients. AJR Am J Roentgenol 1996, I67(3):683-687.

4. Oueslati S, Douira-Khomsi W, Bouaziz MC, Zaouia K: Elastofibroma dorsi: A report on 6 cases. Acta Orthop Belg 2006, 72(2):237-242.

5. Marin ML, Perzin KH, Markowitz AM: Elastofibroma dorsi: benign chest wall tumor. J Thorac Cardiovasc Surg 1989, 98(2):234-238.

6. Brandser EA, Goree JC, El-Khoury GY: Elastofibroma dorsi: prevalence in an elderly patient population as revealed by $C T$. AJR Am J Roentgenol 1998, I 7 I(4):977-980.

7. Giebel GD, Bierhoff E, Vogel J: Elastofibroma and pre-elastofibroma--a biopsy and autopsy study. Eur J Surg Oncol 1996, 22( I):93-96.

8. Jarvi OH, Lansimies PH: Subclinical elastofibromas in the scapular region in an autopsy series. Acta Pathol Microbiol Scand [A] 1975, 83(I):87-108.

9. Jarvi O, Saxen E: Elastofibroma dorsi. Acta Pathol Microbiol Scand | 96|, 5 I (Suppl | 44):83-84. 
10. Machens HG, Mechtersheimer R, Gohring U, Schlag PN: Bilateral elastofibroma dorsi. Ann Thorac Surg 1992, 54(4):774-776.

II. Hoffman JK, Klein MH, Mclnerney VK: Bilateral elastofibroma: a case report and review of the literature. Clin Orthop Relat Res 1996:245-250

12. Stemmermann GN, Stout AP: Elastofibroma dorsi. Am J Clin Pathol 1962, 37:499-506.

13. Winkelmann RK, Sams WM Jr.: Elastofibroma. Report of a case with special histochemical and electron-microscopic studies. Cancer 1969, 23(2):406-4I5.

14. De Nictolis M, Goteri G, Campanati G, Prat J: Elastofibrolipoma of the mediastinum. A previously undescribed benign tumor containing abnormal elastic fibers. Am J Surg Pathol 1995, 19(3):364-367.

15. Renshaw TS, Simon MA: Elastofibroma. J Bone Joint Surg Am 1973 , 55(2):409-4I2.

16. Prete PE, Henbest M, Michalski JP, Porter RW: Intraspinal elastofibroma. A case report. Spine 1983, 8(7):800-802.

17. Deutsch GP: Elastofibroma dorsalis treated by radiotherapy. Br J Radiol I 974, 47(56I):62 I-623.

18. Mohan JC, Goel PK, Gambhir DS, Khanna SK, Arora R: Calcified mobile papillary fibroelastoma of the tricuspid valve: a case report. Indian Heart ] 1987, 39(3):237-239.

19. Enjoji M, Sumiyoshi K, Sueyoshi K: Elastofibromatous lesion of the stomach in a patient with elastofibroma dorsi. Am J Surg Pathol I985, 9(3):233-237.

20. Fukuda $Y$, Miyake H, Masuda $Y$, Masugi $Y$ : Histogenesis of unique elastinophilic fibers of elastofibroma: ultrastructural and immunohistochemical studies. Hum Pathol I 987, 1 8(5):424-429.

21. Sakae K: Elastofibroma dorsi: Clinicopathological and electron microscope studies. Acta Med Univ Kagoshimaensis 1973, 25(3): $1-29$.

22. Akhtar M, Miller RM: Ultrastructure of elastofibroma. Cancer 1977, 40(2):728-735

23. Jarvi OH, Saxen AE, Hopsu-Havu VK, Wartiovaara JJ, Vaissalo VT: Elastofibroma--a degenerative pseudotumor. Cancer 1969 , 23(I):42-63.

24. Majo J, Gracia I, Doncel A, Valera M, Nunez A, Guix M: Elastofibroma dorsi as a cause of shoulder pain or snapping scapula. Clin Orthop Relat Res 2001:200-204.

25. Greenberg JA, Lockwood RC: Elastofibroma dorsi. A case report and review of the literature. Orthop $\operatorname{Rev} 1989$, I 8(3):329-333.

26. Yu JS, Weis LD, Vaughan LM, Resnick D: MRI of elastofibroma dorsi. J Comput Assist Tomogr 1995, 19(4):60 I-603.

27. Soler R, Requejo I, Pombo F, Saez A: Elastofibroma dorsi: MR and CT findings. Eur J Radiol 1998, 27(3):264-267.

28. Massengill AD, Sundaram M, Kathol MH, el-Khoury GY, Buckwalter $\mathrm{JH}$, Wade TP: Elastofibroma dorsi: a radiological diagnosis. Skeletal Radiol 1993, 22(2): I21-123.

29. Malghem J, Baudrez V, Lecouvet F, Lebon C, Maldague B, Vande Berg $B$ : Imaging study findings in elastofibroma dorsi. Joint Bone Spine 2004, 7 I (6):536-54I.

30. Schick S, Zembsch A, Gahleitner A, Wanderbaldinger P, Amann G, Breitenseher M, Trattnig S: Atypical appearance of elastofibroma dorsi on MRI: case reports and review of the literature. J Comput Assist Tomogr 2000, 24(2):288-292.

31. Zembsch A, Schick S, Trattnig S, Walter J, Amann G, Ritschl P: Elastofibroma dorsi. Study of two cases and magnetic resonance imaging findings. Clin Orthop Relat Res 1999:213-219.

32. Kransdorf MJ, Meis JM, Montgomery E: Elastofibroma: MR and CT appearance with radiologic-pathologic correlation. AJR Am J Roentgenol 1992, 159(3):575-579.

33. Pierce JC 3rd, Henderson R: Hypermetabolism of elastofibroma dorsi on PET-CT. AJR Am J Roentgenol 2004, I 83(I):35-37.

34. Cota C, Solivetti F, Kovacs D, Cristiani R, Amantea A: Elastofibroma dorsi: histologic and echographic considerations. Int J Dermatol 2006, 45(9): I 100-I I03

35. Bianchi S, Martinoli C, Abdelwahab IF, Gandolfo N, Derchi LE, Damiani S: Elastofibroma dorsi: sonographic findings. $A J R A m J$ Roentgenol 1997, 169(4): I II3-III5.

36. Solivetti FM, Bacaro D, Di Luca Sidozzi A, Cecconi P: Elastofibroma dorsi: ultrasound pattern in three patients. J Exp Clin Cancer Res 2003, 22(4):565-569.
37. Baudrez V, Malghem J, Van de Berg B, Lebon C, Lecouvet F, Maldague $B$ : [Ultrasonography of dorsal elastofibroma. Apropos of 6 cases]. J Radiol I998, 79(6):549-55|.

38. Gould ES, Javors BR, Morrison J, Potter H: MR appearance of bilateral periscapular elastofibromas. J Comput Assist Tomogr 1989, 13(4):70|-703.

39. Kudo S: Elastofibroma dorsi: $\mathbf{C T}$ and $\mathbf{M R}$ imaging findings. Semin Musculoskelet Radiol 200I, 5(2): I03-105.

40. Nishida A, Uetani M, Okimoto T, Hayashi K, Hirano T: Bilateral elastofibroma of the thighs with concomitant subscapular lesions. Skeletal Radiol 2003, 32(2): I I6-1 I8.

4I. Pisharodi LR, Cary D, Bernacki EG Jr.: Elastofibroma dorsi: diagnostic problems and pitfalls. Diagn Cytopathol 1994, 10(3):242-244.

42. Berthoty DP, Shulman HS, Miller HA: Elastofibroma: chest wall pseudotumor. Radiology 1986, I60(2):341-342.

43. Ghiatas AA, Armstrong S, Tio FO: Case report 583: Elastofibroma dorsi. Skeletal Radiol 1989, I 8(8):619-622.

44. Lang P, Suh KJ, Grampp S, Steinbach L, Steiner E, Peterfy C, Tirman P, Schwickert $H$, Rosenau W, Genant HK: [CT and MRI in elastofibroma. A rare, benign soft tissue tumor]. Radiologe 1995, 35(9):6||-6|5.

45. Liessi G, Tregnaghi A, Barbazza R, Scapinello A, Muzzio PC: Elastofibroma: CT and MR findings. J Belge Radiol I99I, 74(I):37-39.

46. Domanski HA, Carlen B, Sloth M, Rydholm A: Elastofibroma dorsi has distinct cytomorphologic features, making diagnostic surgical biopsy unnecessary: cytomorphologic study with clinical, radiologic, and electron microscopic correlations. Diagn Cytopathol 2003, 29(6):327-333

47. Nakamura $Y$, Ohta $Y$, Itoh S, Haratake A, Nakano Y, Umeda A, Shima $\mathrm{H}$, Tomoda N: Elastofibroma dorsi. Cytologic, histologic, immunohistochemical and ultrastructural studies. Acta Cytol 1992, 36(4):559-562.

48. Dixon AY, Lee SH: An ultrastructural study of elastofibromas. Hum Pathol 1980, I I(3):257-262.

49. Schafmayer C, Kahlke V, Leuschner I, Pai M, Tepel J: Elastofibroma dorsi as differential diagnosis in tumors of the thoracic wall. Ann Thorac Surg 2006, 82(4): I50I-I 504.

50. McGregor JC, Rao SS: Elastofibroma: a rare cause of painful shoulder. Br J Surg 1974, 6 I (7):583-584.
Publish with Biomed Central and every scientist can read your work free of charge

"BioMed Central will be the most significant development for disseminating the results of biomedical research in our lifetime. "

Sir Paul Nurse, Cancer Research UK

Your research papers will be:

- available free of charge to the entire biomedical community

- peer reviewed and published immediately upon acceptance

- cited in PubMed and archived on PubMed Central

- yours - you keep the copyright
BioMedcentral 